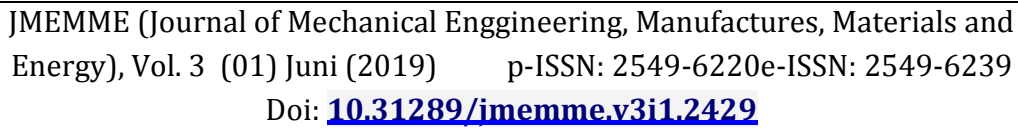

JMEMME (Journal of Mechanical Engineering, Manufactures, Materials and Energy)

\title{
ANALISA KINERJA MATA PISAU MESIN PENGIRIS KULIT KELAPA MUDA
}

\section{PERFORMANCE ANALYSIS OF THE BLADES OF THE YOUNG COCONUT SKIN SLICER MACHINE}

\author{
Bobby Umroh*, Darianto, Rinto Supardi Sipangkar \\ Program Studi Teknik Mesin, Universitas Medan Area \\ Diterima: 12-04-2019 ; Disetujui: 24-06-2019 ; Diterbitkan: 30-06-209 \\ *Corresponding author: : bobbyumroh@staff.uma.ac.id
}

\begin{abstract}
Abstrak
Kelapa muda umumnya disajikan secara alami dengan bentuk kerucut di atas. Proses pembentukan kelapa ini sudah dilakukan secara manual di industri rumah tangga dengan menggunakan sebilah parang. Proses ini memiliki resiko kecelakaan kerja yang tinggi. Kelapa yang dihasilkan pada proses ini memiliki bentuk yang kurang menarik, tidak seragam, dan sulit untuk dibuka. Oleh sebab itu, dibutuhkan alat pengiris kulit kelapa muda yang dapat menghasilkan bentuk yang lebih baik, seragam, dan aman untuk digunakan. Untuk merancang alat pengiris kulit kelapa muda, penting untuk melakukan analisis mekanisme pemotongan kulit kelapa muda. Tujuan dari penelitian ini adalah untuk menganalisis mekanisme pemotongan kulit kelapa muda, membangun model matematika pendugaan gaya spesifik pemotongan, dan mendapatkan daya pemotongan maksimum pemotongan kulit kelapa muda. Variasi faktor sudut ketajaman, sudut potong, dan sisi mata pisau dioptimalkan untuk menghasilkan gaya potong terendah. Model matematika telah dibangun untuk menduga gaya pemotongan maksimum untuk pisau satu sisi menajam dan dua sisi menajam dengan sudut potong $(\theta) 00,15^{0}$, dan $30^{\circ}$. Dari hasil penelitian disimpulkan bahwa jenis pisau yang menghasilkan gaya pemotongan terendah adalah pisau dua sisi menajam dengan sudut ketajaman $10^{\circ}$ dan sudut potong 30 Daya terendah untuk pemotongan tegak lurus kulit kelapa muda adalah $0,12 \mathrm{~kW}$ yang dihasilkan dengan menggunakan pisau dua sisi menajam dengan sudut ketajaman $10^{\circ}$ dan sudut potong $30^{\circ}$. Daya pemutaran maksimum yang dibutuhkan untuk memotong kulit kelapa muda adalah $0,75 \mathrm{~kW}$.
\end{abstract}

Kata kunci: Gaya pemotongan, model matematika, pisau, kulit kelapa muda, sudut potong

\begin{abstract}
Young coconut is generally presented naturally with the cone shape above. This coconut formation process has been done manually in the home industry using a machete. This process has a high risk of work accidents. Coconut was produced in this process has a shape that is less attractive, not uniform, and difficult to open. Therefore, it takes a young coconut skin slicer that can produce a better, uniform, and safe form to use. To design young coconut skin slicer, it is important to analyze the cutting mechanism of young coconut skin. The purpose of this study was to analyze the cutting mechanism of young coconut skin, build a mathematical model for estimating the specific style of cutting, and get the maximum cutting power of young coconut skin. Variations in sharpness angle, cutting angle, and blade side are optimized to produce the lowest cutting force. A mathematical model has been constructed to estimate the maximum cutting force for a one -sided blade sharpening and two sharpened edges with cutting angles $(\theta) 0^{\circ}, 150$, and $30^{\circ}$. From the results of the study concluded that the type of knife that produces the lowest cutting force is a twosided blade sharpening with an angle sharpness of $10^{\circ}$ and angle of cut $30^{\circ}$. The lowest power for cutting perpendicular to young coconut skin is $0.12 \mathrm{~kW}$ which is produced using a sharpened two-sided knife with a sharpness angle of $100^{\circ}$ and a cutting angle of 300. The maximum playback power needed to cut young coconut skin is $0.75 \mathrm{~kW}$.
\end{abstract}

Keywords: Cutting style, mathematical model, knife, young coconut skin, cutting angle 
Umroh, B., Analisa Kinerja Mata Pisau Mesin Pengiris Kulit Kelapa Muda

How to Cite: Umroh, B., 2019, Analisa Kinerja Mata Pisau Mesin Pengiris Kulit Kelapa Muda, JMEMME (Journal of Mechanical Engineering Manufactures Materials and Energy), 3 (01): 29-38. 


\section{PENDAHULUAN}

Tanaman kelapa telah ada sejak ratusan tahun dikenal di seluruh kepulauan Nusantara. Kelapa merupakan salah satu penghasil bahan makanan yang sangat penting dalam kehidupan rakyat Indonesia. Hal ini dapat dilihat dari kenyataan bahwa $75 \%$ dari minyak nabati dan $8 \%$ dari konsumsi protein bersumber dari kelapa. Selain itu tanaman kelapa merupakan tanaman serba guna, yang keseluruhan bagiannya dimanfaatkan bagi kehidupan manusia dan menghasilkan keuntungan. Oleh karena itu kelapa mempunyai arti yang sangat penting bagi kehidupan dan perekonomian di Indonesia. Produksi mencakup setiap usaha manusia untuk menambah, mempertinggi dan atau mengadakan nilai atas kurang dan jasa, hingga barang-barang itu berfaedah bagi manusia. Atau dengan perkataan lain usaha orang yang akhirnya dapat menambah faedah dari barang. Sedangkan alat produksi dapat dikategorikan sebagai barang produksi, yakni barang yang digunakan untuk menghasilkan barang lain yang lebih berguna. Jadi dalam hal ini barang produksi tidak langsung untuk konsumsi, melainkan dipergunakan sebagai sarana dalam melaksanakan atau memperlancar proses produksi (Depdikbud, 2001).

Pemotongan kelapa muda hingga pada saat sekarang ini masih banyak yang menggunakan peralatan tradisional ataupun konvensional yaitu dengan menggunakan parang ataupun pisau suatu alat yang terbuat dari besi. Pemotongan kelapa muda dengan cara ini memiliki kelemahan antara lain yaitu operator yang memotong kulit kelapa harus benar-benar berpengalaman, memiliki tingkat ketelitian yang tinggi, kapasitas kerja yang relative terbatas, serta tingkat kecelakaan kerja yang tinggi. Untuk mengatasi keterbatasan ataupun kelemahan tersebut, maka dibuatlah mesin pemotong kulit kelapa muda yang mampu memotong kulit kelapa muda dengan mudah dan cepat serta dapat dioperasikan dengan kinerja yang sama oleh siapapun operatornya, serta memiliki kecelakaan kerja yang sangat rendah.

\section{METODOLOGI}

Alat yang digunakan dalam penelitian adalah:

a. Jangka sorong

Jangka sorong berfungsi untuk mengukur diameter ketebalan dari mata pisau yang akan di analisa.

b. Baja Siku

Baja siku berfungsi untuk mengukur kerataan/kedataran mata pisau yang digunakan pada mesin pengiris kulit kelapa muda.

c. Rol baja

Rol baja digunakan untuk mengukur panjang dan lebar mata pisau yang digunakan pada mesin pengiris kulit kelapa muda dan bahan yang digunakan adalah satu unit mesin pengiris kulit kelapa muda untuk bahan analisa.

Data-data yang akan di kumpulkan yaitu:

1. Jumlah buah kelapa yang dapat di iris oleh mesin selama waktu yang ditentukan.

2. Kerapian/kebersihan pengirisan mata pisau pada saat bekerja.

Setelah data-data dari yang di kumpulkan semua terkumpul, maka langkah selanjutnya adalah mengolah serta menganalisis data dengan menggunakan rumus yang dibutuhkan untuk menghitung data yang sudah terkumpul dari hasil analisa. 
Umroh, B., Analisa Kinerja Mata Pisau Mesin Pengiris Kulit Kelapa Muda

\section{HASIL DAN PEMBAHASAN}

Sebelum melakukan penelitian analisis gaya spesifik pemotongan kulit kelapa muda, terlebih dahulu dilakukan pengambilan data sifat fisik dan mekanik kulit kelapa muda. Pengamatan sifat fisik kelapa muda difokuskan pada dimensi buah kelapa muda. Hasil pengamatan ini akan digunakan untuk merancang dimensi pisau potong. Bentuk dan data sifat fisik tersebut diperlihatkan pada gambar 1 dan table 1.

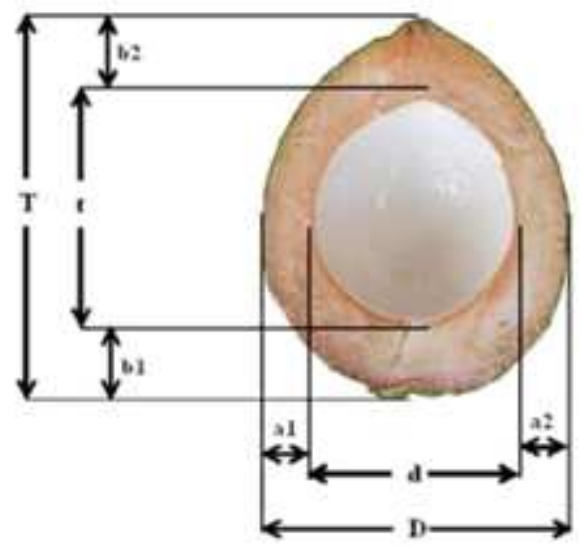

Gambar 1. Bagian Kelapa Muda Dengan Label Pada Setiap Dimensi

Tabel 1. Sifat fisik kelapa muda

\begin{tabular}{ll}
\hline \multicolumn{1}{c}{$\begin{array}{c}\text { Data sifat fisik } \\
\text { kelapa muda } \\
\text { hijau }\end{array}$} & Dimensi (mm) \\
\hline $\begin{array}{l}\text { Tinggi buah (H) } \\
\text { Diameter buah }\end{array}$ & $227,70 \pm 6,83$ \\
(D) & $170,90 \pm 3,51$ \\
$\begin{array}{l}\text { Tinggi cangkang } \\
\text { (h) }\end{array}$ & $145,4 \pm 4,9437$ \\
Diamater & $10,93 \pm 4,96$ \\
cangkang (d) & \\
Jarak vertikal & $46,43 \pm 2,98$ \\
antara cangkang & \\
dengan dasar & \\
buah (b1) & \\
Jarak vertikal & $34,87 \pm 3,95$ \\
\hline
\end{tabular}

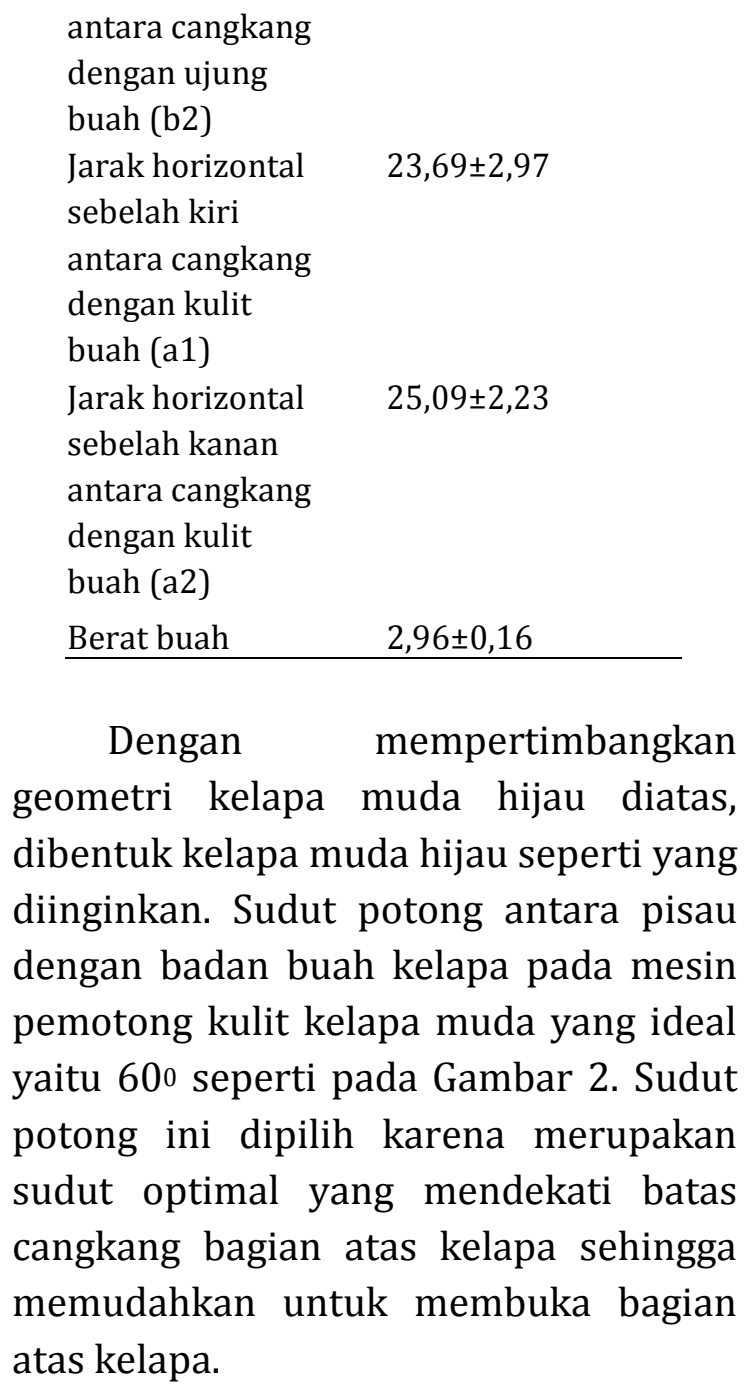

Dengan mempertimbangkan geometri kelapa muda hijau diatas, dibentuk kelapa muda hijau seperti yang diinginkan. Sudut potong antara pisau dengan badan buah kelapa pada mesin pemotong kulit kelapa muda yang ideal yaitu $60^{0}$ seperti pada Gambar 2. Sudut potong ini dipilih karena merupakan sudut optimal yang mendekati batas cangkang bagian atas kelapa sehingga memudahkan untuk membuka bagian atas kelapa.

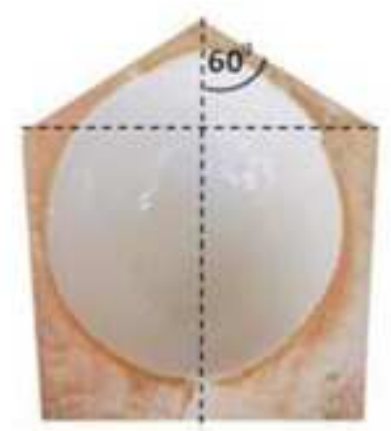

Gambar 2. Sudut pemotongan kelapa muda hijau

$$
\text { Untuk membangun model }
$$
matematika gaya spesifik pemotongan kulit kelapa muda, dibutuhkan data-data sifat mekanik kelapa muda yang bekerja pada mekanisme pemotongan. Karakteristik mekanik kulit kelapa muda yang diukur yaitu modulus elastisitas, 
poisson ratio, strength maximum, dan koefisien gesek. Hasil pengukuran sifat mekanik kelapa muda dapat dilihat pada Tabel 2.

$\underline{\text { Tabel 2. Sifat Mekanik Kulit Kelapa Muda }}$

\begin{tabular}{ll}
\hline $\begin{array}{l}\text { Karakteristik } \\
\text { mekanik }\end{array}$ & Nilai \\
\hline Modulus elastisitas & $4,30 \mathrm{Mpa}$ \\
Poisson ratio & 0,35 \\
Strength Maximum & $0,47 \mathrm{Mpa}$ \\
Koefisien gesek & 0,35 \\
\hline
\end{tabular}

Mekanisme Pemodelan Matematika Gaya Spesifik Pemotongan

Model matematika gaya spesifik pemotongan dibangun dari parameterparameter pada pisau pemotong yaitu bentuk sisi mata pisau, sudut ketajaman, dan sudut potong yang dihubungkan dengan gaya-gaya yang bekerja pada mekanisme pemotongan kulit kelapa muda. Pada mata pisau satu sisi menajam dengan sudut potong 0 , gaya normal yang bekerja pada bidang miring pisau merupakan penjumlahan komponen gaya horisontal dan gaya vertikal seperti pada gambar. Dari hasil analisis pada gambar, didapatkan gaya-gaya yang bekerja pada pisau satu sisi menajam. Gaya-gaya tersebut kemudian dijabarkan untuk mendapatkan nilainya.

Dari hasil analisis diketahui bahwa sifat mekanik yang mempengaruhi besarnya gaya-gaya pada saat pemotongan yaitu modulus elastisitas (E), koefisien gesek (m), poisson ratio (v), dan strength maksimum (s). Komponen gaya yang bekerja pada mekanisme pemotongan kulit kelapa muda kemudian dijabarkan pada Persamaan 1 sampai 6. Gaya-gaya tersebut diturunkan terhadap kedalaman potong (h). Lebar bahan yang digunakan pada pemodelan ini (l) yaitu $5 \mathrm{~cm}$ dan tinggi bahan $(\mathrm{H})$ yaitu $2 \mathrm{~cm}$. Gaya Fv dan Fh ditentukan dengan pendekatan sifat deformasi bahan. Ketebalan pisau (d) yang digunakan yaitu $3 \mathrm{~mm}$. Penjumlahan gaya-gaya yang bekerja pada pisau dengan satu sisi mata pisau menajam dapat dilihat pada Persamaan 7.

$$
\begin{aligned}
& N=F_{v} \sin \beta+F_{h} \cos \beta \\
& F e=A \sigma_{B}=\delta l \sigma_{B} \\
& d F v=\varepsilon E \tan \beta d h=(\mathrm{E} / 2 \mathrm{H}) h^{2} \tan \beta \\
& d F h=v \varepsilon E d h=v(E / 2 H) h^{2} \\
& T_{1}=\mu F_{h}=\mu(v E / 2 H) h^{2} \\
& T_{12}=T_{2} \cos \beta=\mu\left[\left(\frac{1}{2} F_{v} \sin 2 \beta+\right.\right. \\
& \left.\left.F_{h} \cos ^{2} \beta\right)\right] \\
& F=F_{e}+F_{v}+T_{1}+T_{2}
\end{aligned}
$$

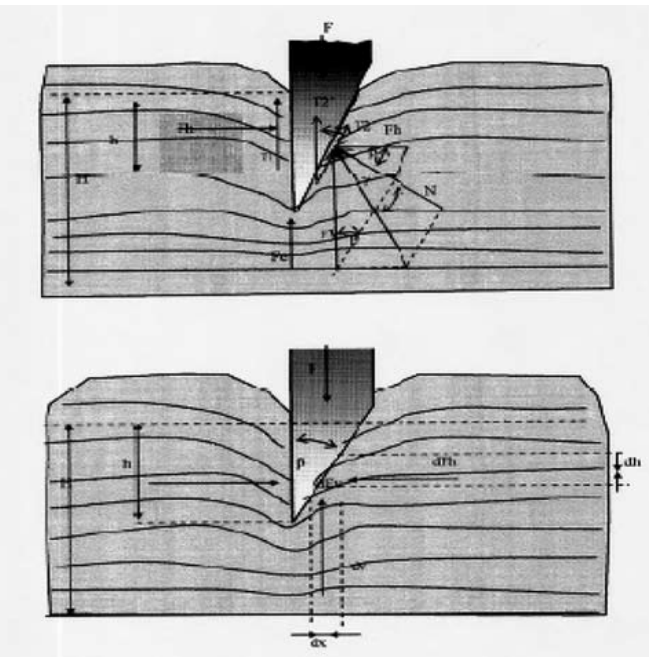

Gambar 3. Gaya-Gaya Yang Terjadi Pada Pisau Satu Sisi Menajam

Gambar menunjukkan gaya-gaya yang bekerja pada pisau dengan dua sisi menajam. Analisis yang sama juga dilakukan pada pisau dua sisi menajam dengan memasukkan komponen gayagaya yang bekerja seperti pada pisau satu sisi menajam. Penjumlahan gayagaya yang bekerja pada pisau dengan dua sisi menajam dapat dilihat pada Persamaan 8. 
Umroh, B., Analisa Kinerja Mata Pisau Mesin Pengiris Kulit Kelapa Muda

$$
F=F_{e}+2\left(F_{v}+T_{2}+\frac{1}{2} A T_{1}\right)
$$

Setelah dilakukan analisis terhadap gaya gaya yang bekerja pada mekanisme pemotongan, dibangun persamaan gaya spesifik pemotongan pada pisau satu sisi menajam (Persamaan 9) dan dua sisi menajam (Persamaan 10) untuk sudut potong $0^{\circ}$.

$$
\begin{aligned}
& F=\delta \sigma l+\frac{E l}{2 H} h^{2}\left(\tan \beta+\mu \sin ^{2} \beta+v \mu+\right. \\
& v \mu \cos ^{2} \beta
\end{aligned}
$$

$F=\delta \sigma l+2 \frac{E l}{2 H} h^{2}\left(\tan \frac{\beta}{2}+\mu \sin ^{2} \frac{\beta}{2}+\right.$

$\left.v \mu \cos ^{2} \frac{\beta}{2}+\frac{1}{2} \mu v\right)$

Dimana :

ß : sudut ketajaman mata pisau

$\theta$ : sudut pemotongan

E : modulus elastisitas

$\mathrm{v}$ : poisson ratio

$\mathrm{H}$ : tinggi bahan

h : perubahan kedalaman potong pada tinggi bahan

l : lebar bahan

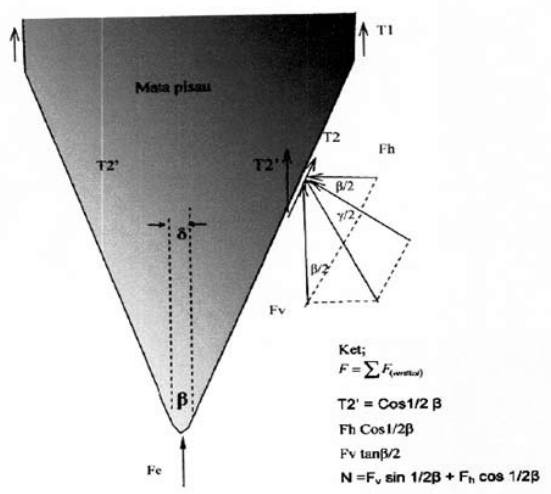

Gambar 4. Gaya-Gaya Yang Terjadi Pada Pisau Dua Sisi Menajam

\section{Perbandingan Matematika antara \\ Model Gaya Spesifik Pemotongan dan Gaya Pemotongan Aktual}

Dari grafik pada Gambar 5 dan 6, diketahui bahwa pisau dengan dua sisi menajam cenderung memerlukan gaya potong yang lebih rendah dari pada pisau satu sisi menajam. Hal ini terjadi karena pada pisau dua sisi menajam membentuk sudut tersebut dari dua sisi yang mengakibatkan gaya menyebar merata dan gaya gesek lebih rendah. Kecenderungan semakin besar sudut ketajaman ( $\beta$ ) maka gaya spesifik pemotongan maksimum akan semakin tinggi.

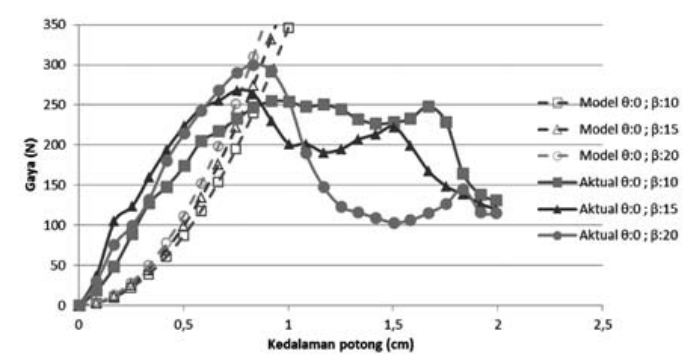

(a)

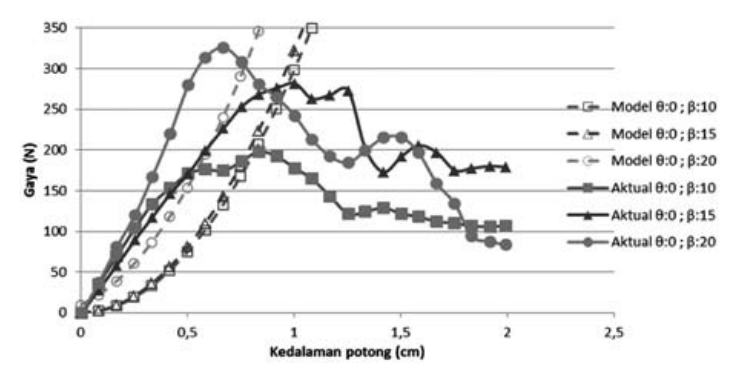

(b)

Gambar 5. Grafik perbandingan gaya pemotongan kulit kelapa muda aktual dan model untuk $\theta=0$ : (a) Pisau satu sisi menajam, (b) Pisau dua sisi menajam 


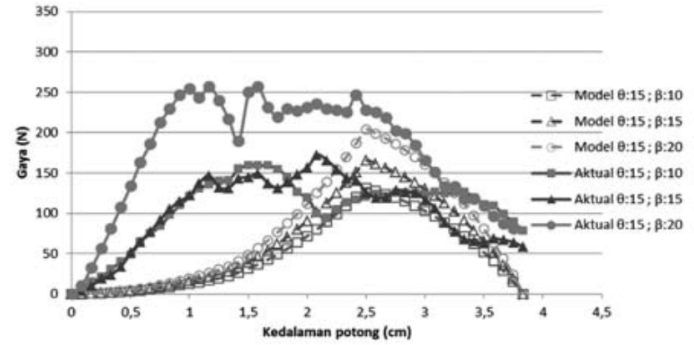

(a)

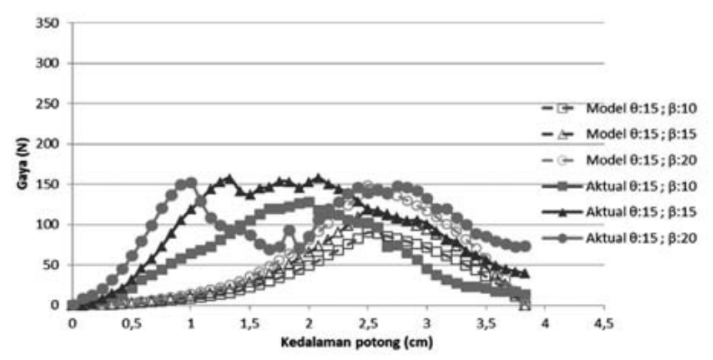

(b)

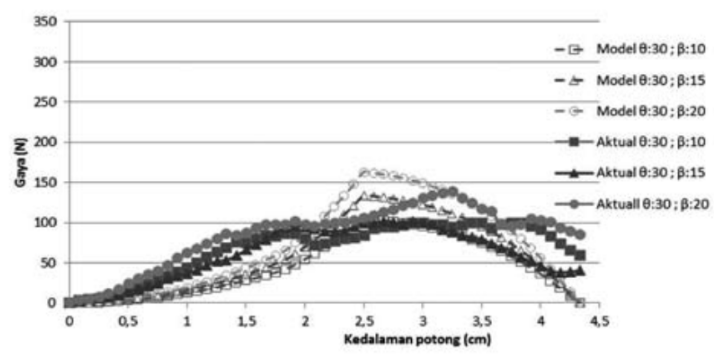

(c)

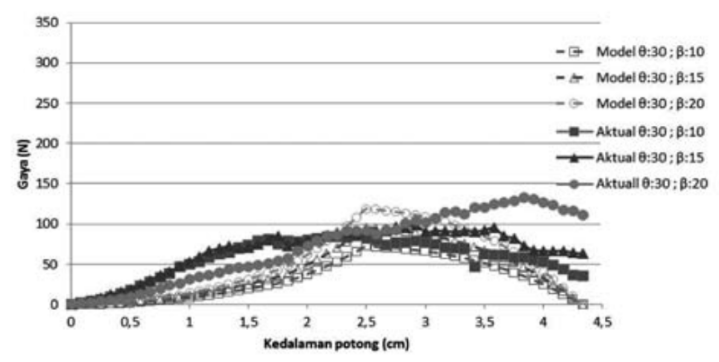

(d)

Gambar 6. Grafik Perbandingan Gaya Pemotongan Kulit Kelapa Muda Aktual Dan Model Untuk $\Theta>0^{\circ}$ : (a) Pisau satu sisi menajam pada $\theta: 15^{\circ}$, (b) Pisau dua sisi menajam $\theta: 15^{\circ}$, (c) Pisau satu sisi menajam pada $\theta: 30^{\circ}$, (d) Pisau dua sisi menajam pada $\theta: 30^{\circ}$

Dari grafik pada Gambar 6, diketahui bahwa pisau dengan dua sisi menajam cenderung memerlukan gaya potong yang lebih rendah dari pada pisau satu sisi menajam. Hal ini terjadi karena pada pisau dua sisi menajam membentuk sudut tersebut dari dua sisi simetris yang mengakibatkan gaya menyebar merata dan gaya gesek lebih rendah.

Dari grafik pada Gambar 6, diketahui bahwa pisau dengan dua sisi menajam cenderung memerlukan gaya potong yang lebih rendah dari pada pisau satu sisi menajam. Hal ini terjadi karena pada pisau dua sisi menajam membentuk sudut tersebut dari dua sisi yang mengakibatkan gaya menyebar merata dan gaya gesek lebih rendah. Kecenderungan semakin besar sudut ketajaman ( $\beta$ ) maka gaya spesifik pemotongan maksimum akan semakin tinggi.

\section{Pengaruh Variasi Pisau terhadap Gaya Pemotongan Kulit Kelapa Muda}

Dari hasil analisis sidik ragam (ANOVA) gaya pemotongan kulit kelapa muda, diketahui bahwa faktor yang berpengaruh pada gaya yang dihasilkan adalah faktor sudut ketajaman pisau dan sudut potong seperti yang terlihat pada Tabel 4. Faktor ini kemudian diuji lanjut Duncan (DMRT) pada taraf 5\%. Dari Tabel 5 dapat ditentukan bahwa pisau dua sisi menajam dengan sudut ketajaman $10^{\circ}$ pada sudut pemotongan $30^{\circ}$ menghasilkan gaya potong kulit kelapa muda terendah yaitu $0,087 \mathrm{kN}$. Model matematika juga menghasilkan gaya terendah pada pisau dua sisi menajam dengan sudut ketajaman $10^{\circ}$ pada sudut pemotongan $30^{\circ}$ yaitu 0,072 kN. Prediksi kebutuhan gaya pada model 
sudah mendekati kebutuhan gaya pada pemotongan aktual.

Tabel 3. Uji lanjut Duncan gaya pemotongan terhadap sudut ketajaman

\begin{tabular}{llll}
\hline $\begin{array}{l}\text { Duncan } \\
\text { Grouping }\end{array}$ & Mean & $\mathrm{N}$ & Sudut \\
\hline $\mathrm{A}$ & 0.23844 & 18 & 20 \\
$\mathrm{AB}$ & 0.21011 & 18 & 15 \\
$\mathrm{~B}$ & 0.17717 & 18 & 10 \\
\hline
\end{tabular}

Tabel 4. Uji lanjut Duncan gaya pemotongan terhadap sudut potong

\begin{tabular}{llll}
\hline $\begin{array}{l}\text { Duncan } \\
\text { Grouping }\end{array}$ & Mean & $\mathrm{N}$ & Sudut \\
\hline $\mathrm{A}$ & 0.26328 & 18 & 0 \\
$\mathrm{~A}$ & 0.21333 & 18 & 15 \\
$\mathrm{~B}$ & 0.14911 & 18 & 30 \\
\hline
\end{tabular}

Kebutuhan Daya

Analisis energi dan daya pemotongan dilakukan dengan memasukkan nilai gaya pemotongan dan komponen kondisi bahan uji pada saat melakukan pemotongan. Nilai daya pemotongan maksimum didapat dengan menggunakan Persamaan 17 sampai dengan 19. Bahan kering didapatkan dari perhitungan persentasi bahan kering yang telah diukur pada saat percobaan.

Dari hasil pengukuran, diketahui kebutuhan torsi aktual untuk pemotongan kulit kelapa muda adalah 228,56 Nm dan kecepatan putar adalah 200 rpm. Maka kebutuhan daya pemutaran untuk pemotongan kerucut kelapa muda adalah 0,75 kW. Sedangkan dari hasil perhitungan, nilai torsi yang dihasilkan adalah sebesar 530,54 Nm dan daya pemutaran adalah 1,75 kW. Daya yang dihasilkan pada perhitungan model matematika lebih tinggi dari hasil pengukuran aktual. Hal ini terjadi karena pada model matematika belum dapat memasukkan pengaruh kecepatan pada perhitungan nilai gaya. Kecepatan pemotongan sangat berpengaruh pada kebutuhan energi. Hal ini sesuai dengan penelitian Razavi et al. (2010) pada pemotongan tebu yang menyatakan bahwa perbedaan kebutuhan energi didapatkan pada kecepatan diatas 1,34 $\mathrm{m} / \mathrm{s}$.

\section{Performa Alat Mesin Kelapa Muda}

Mesin pemotong kelapa muda telah dirancang untuk membentuk kerucut pada bagian atas kelapa (gambar di bawah). Alat ini menghasilkan kelapa muda dengan bentuk kerucut yang bagus. Waktu yang dibutuhkan untuk membentuk kerucut pada satu buah kelapa muda adalah 90 detik. Sudut kerucut kelapa muda yang dibentuk adalah $120^{\circ}$. Dari hasil percobaan, sudut kerucut ini ternyata masih belum dapat membuat kelapa muda lebih mudah untuk dibuka karena letak tempurung kelapa masih jauh dari permukaan. Ukuran sudut kerucut kelapa muda ini menjadi kurang efektif karena dimensi kelapa muda hijau yang sangat beragam. Perlu dilakukan pengelompokan kelapa muda berdasarkan dimensinya agar sudut kerucut kelapa yang ditentukan efektif untuk memudahkan membuka kelapa muda. Gambar teknik alat ini dapat dilihat pada Gambar 7 dan 8. 


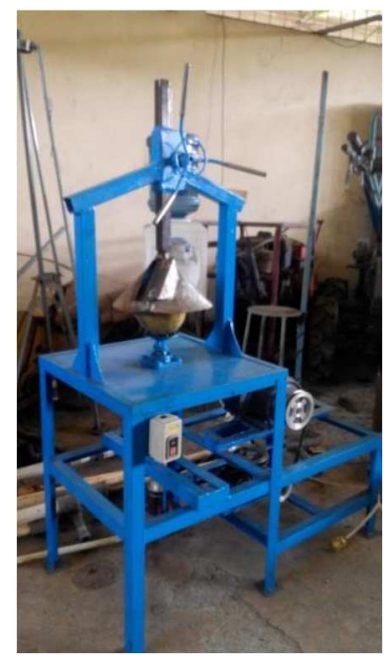

(a)

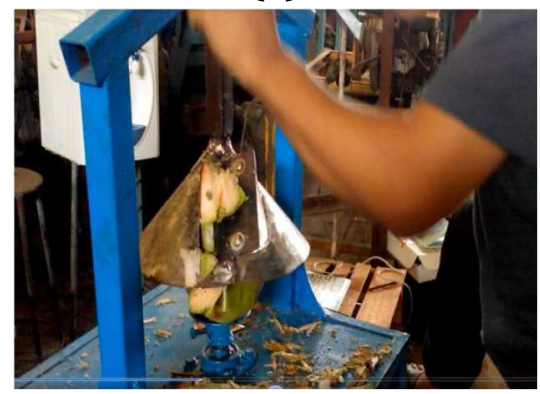

(b)

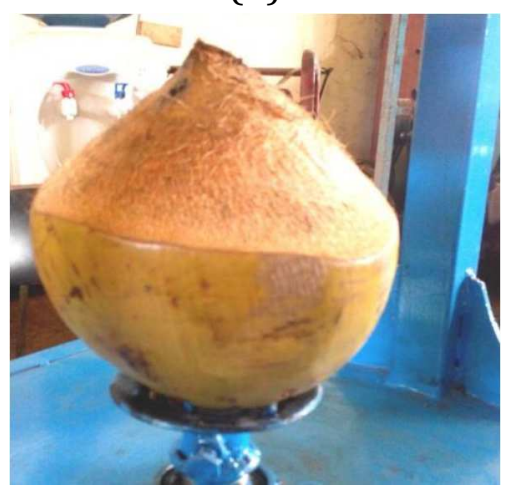

(c)

Gambar 7. Mesin Pemotong Kulit kelapa muda hijau: (a) Mesin Pemotong Kulit kelapa muda, (b) Pemotongan Memutar, (c) Hasil Pemotongan Kelapa

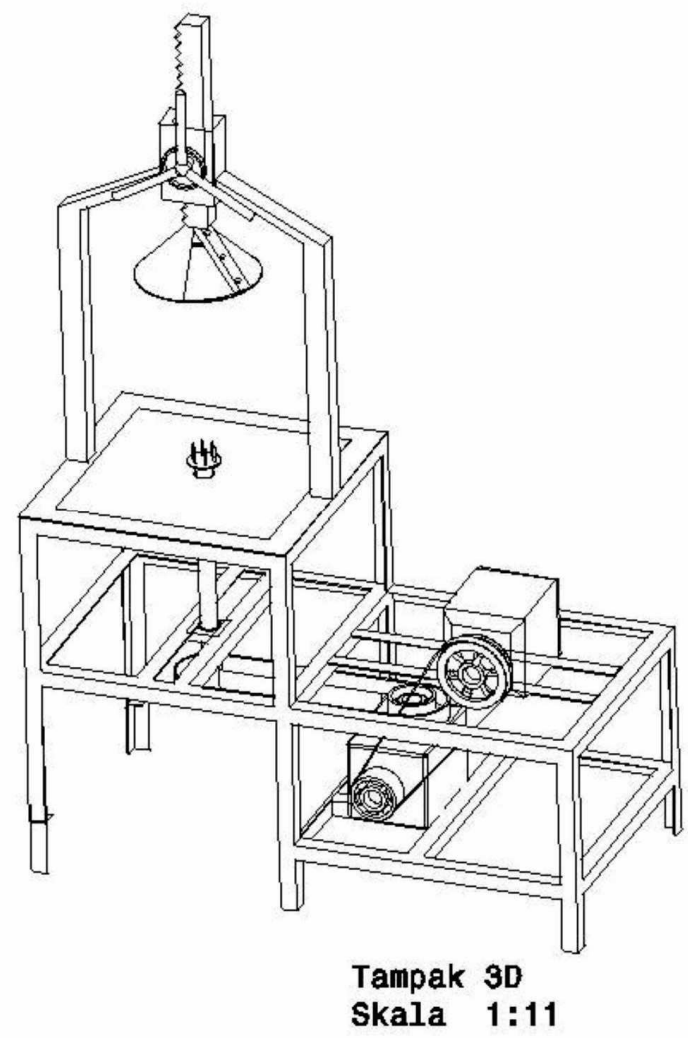

Gambar 8. Gambar Desain Mesin Pemotong Kulit Kelapa Muda

\section{KESIMPULAN}

Sifat mekanik kelapa muda yang mempengaruhi gaya pemotongan kulit kelapa muda adalah modulus elastisitas $(E)$, strength maximum $(\sigma)$, poisson ratio $(v)$, dan koefisien gesek $(\mu)$. Model matematika gaya spesifik pemotongan kulit kelapa muda pada sudut potong $0^{0}$ tidak membatasi tinggi bahan dan tidak memperhitungkan adanya keretakan pada bahan yang mengakibatkan penurunan gaya. Pada sudut potong $30^{\circ}$, kecenderungan pada grafik model sudah mendekati grafik pemotongan aktual. Faktor sudut potong $(\theta)$ dan ketajaman $(\beta)$ berpengaruh nyata pada gaya maksimum yang dihasilkan pada pemotongan kulit kelapa muda. Gaya pemotongan terendah dihasilkan pada pisau dua sisi menajam dengan sudut ketajaman $(\beta) 10^{0}$ dan sudut potong $(\theta)$ 
30․ Model matematika gaya spesifik pemotongan kulit kelapa muda pada sudut potong $(\theta)=0^{0}$ untuk pisau dengan satu sisi menajam dan pisau dengan dua sisi menajam adalah

$$
=0,35+537,6{ }^{2}\left(\tan \beta+0,35 \sin ^{2} \beta\right.
$$

$\left.+0,12+0,35 \cos ^{2} \beta\right)$

Dan

$=0,35+1075,15^{2}\left(\tan \underline{\beta}_{2}+0,35 \sin \right.$

$\left.2 \beta_{2}+, 35 \cos ^{2} \beta_{2}+0,06\right)$

\section{PENGHARGAAN}

Ucapan terima kasih kepada Program Studi Teknik Mesin FT UMA yang telah membantu dan mendukung penelitian ini sehingga dapat diselesaikan dengan baik. Selain itu, kepada rekan-rekan tim riset yang telah banyak membantu dalam penyelesaian riset ini sehingga penelitian ini dapat diselesaikan dengan baik.

\section{REFERENSI}

Hanoto Dkk, 1982. Mekanika Teknik. Bandung : Departemen Pendidikan Nasional.

Khurmi, R.S. Gupta, J.K. 1980. A Text Book of Machine Design. New Delhi: Erlangga

Sato, G. Takeshi,N. Sugiarto Hartanto. 1996. Menggambar Mesin Menurut Standart ISO. Jakarta : PT. Pradyna Paramitha.

Sulaso,Kiyokatsu suga,1987. Dasar Perencanaan dan Pemilihan Elemen Mesin cetakan kesembilan. Jakarta : PT. Pradyna Parmitha.

Suryanto, Drs. 1995. Elemen mesin 1. Bandung : Pusat Pengembangan Politeknik. 